\title{
Effects of Hurricane-Felled Tree Trunks on Soil Carbon, Nitrogen, Microbial Biomass, and Root Length in a Wet Tropical Forest
}

\author{
D. Jean Lodge ${ }^{1, *}$, Dirk Winter ${ }^{2}$, Grizelle González ${ }^{3}$ and Naomi Clum ${ }^{4}$ \\ 1 United States Department of Agriculture, Forest Service, Northern Research Station, \\ Luquillo 00773-1377, Puerto Rico \\ 2 Department of Psychiatry, Columbia University, 180 Ft. Washington Ave., New York, NY 10032, USA; \\ dcw4@caa.columbia.edu \\ 3 United States Department of Agriculture, Forest Service, International Institute of Tropical Forestry, \\ Jardín Botánico Sur, 1201 Ceiba St.-Río Piedras 00926, Puerto Rico; ggonzalez@fs.fed.us \\ 4 Carmel Valley Middle School, 3800 Mykonos Lane, San Diego, CA 92007, USA; naomi.clum@sduhsd.net \\ * Correspondence: dlodge@fs.fed.us or dlodgester@gmail.com or djlodge@caribe.net; Tel.: +1-787-889-7445; \\ Fax: +1-787-889-2080
}

Academic Editors: Scott X. Chang and Xiangyang Sun

Received: 29 August 2016; Accepted: 31 October 2016; Published: 4 November 2016

\begin{abstract}
Decaying coarse woody debris can affect the underlying soil either by augmenting nutrients that can be exploited by tree roots, or by diminishing nutrient availability through stimulation of microbial nutrient immobilization. We analyzed $C, N$, microbial biomass $C$ and root length in closely paired soil samples taken under versus $20-50 \mathrm{~cm}$ away from large trunks of two species felled by Hugo (1989) and Georges (1998) three times during wet and dry seasons over the two years following the study conducted by Georges. Soil microbial biomass, \% C and \% N were significantly higher under than away from logs felled by both hurricanes (i.e., 1989 and 1998), at all sampling times and at both depths (0-10 and 10-20 cm). Frass from wood boring beetles may contribute to early effects. Root length was greater away from logs during the dry season, and under logs in the wet season. Root length was correlated with microbial biomass $\mathrm{C}$, soil $\mathrm{N}$ and soil moisture $(R=0.36$, 0.18 , and 0.27 , respectively; all $p$ values $<0.05$ ). Microbial biomass $C$ varied significantly among seasons but differences between positions (under vs. away) were only suggestive. Microbial C was correlated with soil $\mathrm{N}(R=0.35)$. Surface soil on the upslope side of the logs had significantly more $\mathrm{N}$ and microbial biomass, likely from accumulation of leaf litter above the logs on steep slopes. We conclude that decaying wood can provide ephemeral resources that are exploited by tree roots during some seasons.
\end{abstract}

Keywords: coarse woody debris; nitrogen cycling; soil carbon; soil nitrogen; tree roots; bark beetle frass; fine root proliferation; nutrient hotspots

\section{Introduction}

Coarse woody (CWD) debris can directly and indirectly affect mineral nutrient availability in underlying soil through inputs of nutrients and carbon compounds in leachates, invertebrate frass and particulate decay products [1-7]. CWD as defined by Harmon et al. [3] is fallen or standing dead wood at least $10 \mathrm{~cm}$ diameter. Nutrient hotspots that develop in soil beneath decaying CWD may be important for maintaining forest soil fertility and provide important resources for trees [5]. As noted by Johnson et al. (2014) [8], the influence of soil nutrient hotspots and hot moments on plant growth is obscured by pooling samples, averaging values and eliminating outliers from data sets since soil nutrient availability to plants often responds non-linearly to nutrient hotspots and 
additions of organic matter [9]. Studies in tropical montane [10] and lowland tropical forests [11-14] show that fine roots of trees differentially proliferate in nutrient hotspots (Sayer and Banin 2016) [15]. Two studies in Australian woodlands [16,17] showed significantly higher C, N and P in soil near logs than $80 \mathrm{~cm}$ away, but other studies elsewhere showed decreases in soil $\mathrm{N}$ associated with CWD [18-21]. A companion study to ours by Zalamea et al. (2016) [22] that was conducted in different plots at Bisley and Río Chiquito located on the opposite side of the Luquillo Mountains from our site, and using somewhat different tree species found no increase in $C$ content in their shallower soil samples $(0-5 \mathrm{~cm})$ under decomposing logs than the deeper strata we studied $(0-10$ and 10-20 cm), though Zalamea et al. (2007) [23] did find more water extractable organic matter beneath logs. Reduced soil $\mathrm{N}$ concentrations associated with CWD in North American temperate forests are thought to result from increased leachates with high $\mathrm{C}: \mathrm{N}$ ratios which depress rates of $\mathrm{N}$ mineralization [18-20], while lower extractable $\mathrm{N}$ with large hurricane inputs of CWD in a tropical forest was attributed to increased microbial immobilization [21]. Tropical and subtropical forests have fast wood decay rates $[7,24,25]$ and soils that are often dominated by highly weathered iron and aluminum clays that bind tightly to phosphorus and make it less available (P-fixing clays). In such tropical and subtropical sites, increases in soil $C$ from the decay of CWD are predicted by the Century model to increase the amount of readily exchangeable phosphorus beginning several years after wood addition, thereby stimulating forest productivity [26]. CWD can also alter the physical characteristics of the underlying soil, such as $\mathrm{pH}$, moisture and temperature $[3,6,16,17,22]$.

Natural events such as storms, fires and bark beetle outbreaks as well as anthropogenic disturbances such as logging and salvage operations can deposit CWD on forest floors, potentially contributing to spatial heterogeneity of soil carbon and mineral nutrient availability [18]. Increasing sea surface temperatures due to climate change are predicted to produce more frequent high-intensity hurricanes and typhoons [27-29], while increasing winter temperatures and drought associated with climate change favor increased bark beetle outbreaks and forest fires in North America [30,31]. Given the increasing frequency of forest disturbance events, it is important to understand the effects of CWD on soil carbon, soil fertility and forest productivity.

Whether soils under CWD create hotspots of nutrient availability that are exploited by tree roots, and conversely, whether nutrient sinks under logs caused by microbial immobilization of limiting nutrients are avoided by tree roots, have received little attention. However, production of fine roots in Amazonian forest leaf litter was shown to be a response to nutrient hotspots [32], while root proliferation in response to localized fertilization has been found useful for determining which mineral nutrients are limiting to tree growth in Hawaii [13] and the Amazon [11]. These studies indicate that root length can be used as a bioindicator of where limiting resources are available in nutrient hotspots.

The objectives of this study in a tropical forest of Puerto Rico were to determine if soil $\mathrm{N}$ and $\mathrm{C}$ and tree root lengths were higher under as compared to away from decomposing logs; whether soil microbial biomass and tree root lengths in the same samples varied inversely with each other, thus suggesting competitive exclusion; whether within paired samples, tree roots were more abundant in resource hotspots; and whether there were temporal patterns in soil N, C, microbial biomass C or root length that varied with soil moisture.

\section{Materials and Methods}

\subsection{Study Area}

The El Verde Research Area of the Luquillo Experimental Forest (LEF), where this study was conducted, is on the western side of the Luquillo Mountains ( $18^{\circ} 18^{\prime} \mathrm{N} ; 65^{\circ} 49^{\prime} \mathrm{W}$; Figure 1). The sites ranged from $350-400 \mathrm{~m}$ asl. Mean annual rainfall is $3500 \mathrm{~mm}$ with a weakly seasonal regime, and mean temperatures are $22-25^{\circ} \mathrm{C}$ [32]. The area is classified as subtropical wet forest based on latitude, potential evapotranspiration and low seasonality according to the Holdridge Life Zone system [32], 
though the moderating effect of the surrounding ocean on temperatures make this comparable to a tropical wet climate despite the higher latitude.

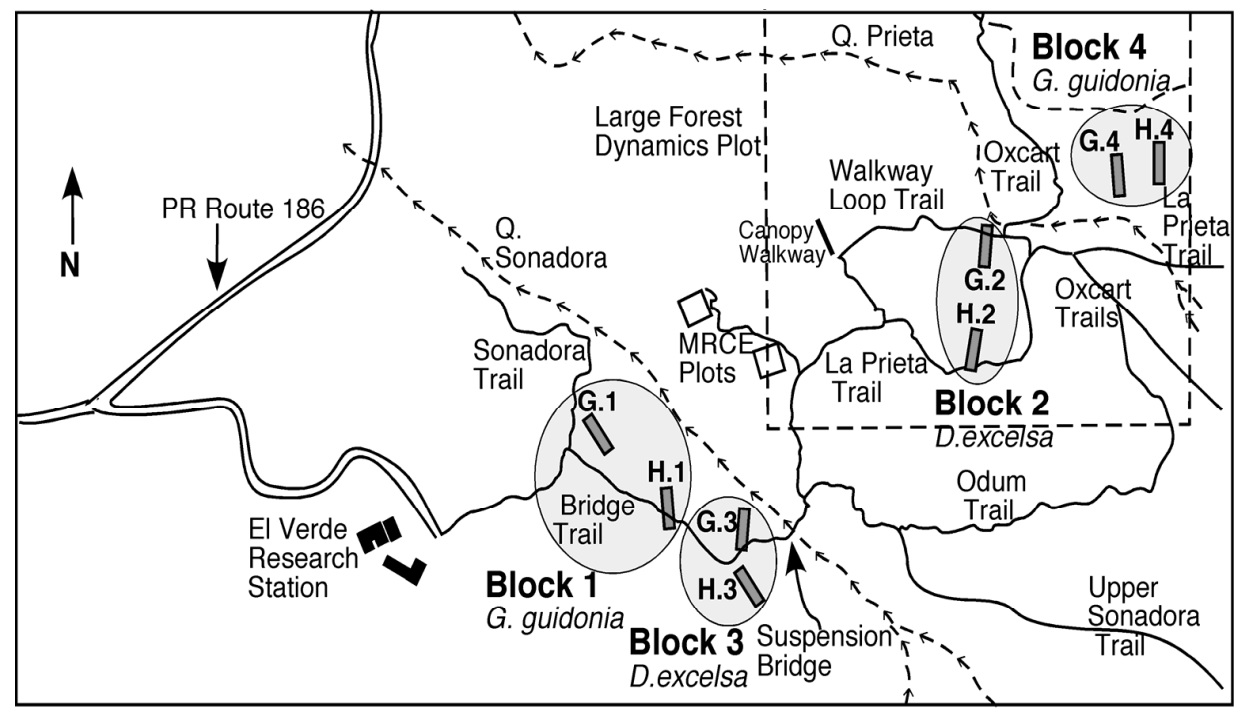

Figure 1. Section of the El Verde Research Area in the Luquillo Experimental Forest of Puerto Rico where this study was conducted, showing the four blocks, each with a pair of logs belonging to two different hurricane cohorts (Hurricane Hugo in 1989 and Hurricane Georges in 1998). The first letter of the log code refers to the hurricane ( $\mathrm{G}$ for Georges and $\mathrm{H}$ for Hugo) while the number refers to the block. Logs in two of the blocks were Dacryodes excelsa Vahl. While the logs in the other two blocks were Guarea guidonia (L.) Sleumer. Direction of stream flow in the Quebrada Prieta and Quebrada Sonadora is indicated by arrows. The logs are not shown to scale.

Soils in the study area are weathered oxisol clay loams and clays ( $30 \%-55 \%$ clay, $28 \%-35 \%$ silt and $18 \%-34 \%$ sand) in the Cristal and Coloso series [33], (Table 1). These clays have a high capacity for binding to phosphorus, but the upper horizon has high soil organic matter content and moderately slow permeability. The Coloso clay series has a higher cation exchange capacity than the Cristal clay loams (43 vs. 29 CEC C $^{-1}$, respectively) [33]. Litter decomposes quickly and humus is usually absent between the forest floor litter and the mineral soil [34], as is typical of mull soils. Leaf litter accumulates on the upslope side of debris dams on slopes $>25 \%$ [9], resulting in higher soil carbon above than below permanent debris dams [35].

Table 1. Location of study blocks and their soil types in the El Verde Research Area of the Luquillo Experimental Forest.

\begin{tabular}{cccc}
\hline Location & Block & Latitude, Longitude & Soil Type \\
\hline Q. Sonadora watershed & 1 & $18^{\circ} 19^{\prime} 24^{\prime \prime} \mathrm{N}, 65^{\circ} 49^{\prime} 03^{\prime \prime} \mathrm{W}$ & Cristal clay-clay loam \\
\hline $\begin{array}{c}\text { Q. Prieta watershed in LFDP } \\
\text { cells 02.09 and 07.10 }\end{array}$ & 2 & $\begin{array}{c}18^{\circ} 19^{\prime} 30.7^{\prime \prime} \mathrm{N}, 65^{\circ} 48^{\prime} 56.6^{\prime \prime} \mathrm{W} \\
18^{\circ} 19^{\prime} 31^{\prime \prime} \mathrm{N}, 65^{\circ} 49^{\prime} 02^{\prime \prime} \mathrm{W}\end{array}$ & Cristal clay-clay loam \\
\hline Q. Sonadora watershed & 3 & $18^{\circ} 19^{\prime} 24^{\prime \prime} \mathrm{N}, 65^{\circ} 49^{\prime} 04^{\prime \prime} \mathrm{W}$ & Cristal clay-clay loam \\
\hline $\begin{array}{c}\text { Q. Prieta watershed in LFDP } \\
\text { cells 10.15 and 10.16 }\end{array}$ & 4 & $\begin{array}{c}18^{\circ} 19^{\prime} 37^{\prime \prime} \mathrm{N}, 65^{\circ} 49^{\prime} 00^{\prime \prime} \mathrm{W} \\
18^{\circ} 19^{\prime} 27^{\prime \prime} \mathrm{N}, 65^{\circ} 49^{\prime} 00^{\prime \prime} \mathrm{W}\end{array}$ & Coloso clay \\
\hline
\end{tabular}

\subsection{Sampling Design}

We examined the effects of decomposing logs of two tree species originating from two major hurricanes, Hugo and Georges, on soil carbon $(\mathrm{C})$ nitrogen $(\mathrm{N})$ content, microbial biomass $\mathrm{C}$ and tree root length in the underlying soil. Soil samples collected at two depths beneath the fallen logs were 
spatially and temporally paired with samples collected $20-50 \mathrm{~cm}$ away. This study on the western side of the Luquillo Mountains was conducted when the hurricane-felled logs were 0.6-1.1 and 9.6-11 years after treefall in the two hurricane cohorts, respectively, and was a precursor to a separate study on the eastern side of the Luquillo Mountains by Zalamea et al. [22,23] when their logs had decayed 6 and 15 years. This study differs in that soils were collected from $0-10$ and $10-20 \mathrm{~cm}$ depths versus $0-5 \mathrm{~cm}$ in Zalamea et al. [22,23], and we used the chloroform fumigation-incubation method [36] to estimate soil microbial biomass $C$ rather than substrate induced respiration technique [37] used in Zalamea et al. [22].

Four areas (blocks) were selected for study, each with a pair of logs of the same species that were at least $30 \mathrm{~cm}$ diameter, with one felled by Hurricane Hugo and one felled by Hurricane Georges (Figure 1). The two species were Dacryodes excelsa Vahl. (Burseraceae) and Guarea guidonia (L.) Sleumer (Meliaceae); there were two replicate blocks of each tree species. Fallen trees were $>30-80 \mathrm{~cm}$ in diameter and at least half of the trunk was in contact with the ground (diameters are given in Table 2). Slopes varied from $20 \%-40 \%$ (Table 2). All logs were decayed by white-rot basidiomycete fungi based on the bleached appearance and spongy-fibrous texture, though rates of decay varied among logs (see Table 2 for details). We used the four-class decay system proposed by Torres (1994) [38] as the decay classification used for logs in temperate forests works poorly in the tropics where the bark can be retained on extensively decayed logs. At the time of this study, the youngest logs (0.6-2 years-old) belonging to the Georges cohort were in decay classes I: no detectable decay, and II: intact bark, sapwood partially soft, and few invading roots present. The older logs belonging to the Hugo cohort (9.5-11 years-old) were in decay II to class III: bark partially lost, sapwood soft, roots invading.

Table 2. Characteristics of logs that were used in this study. The label is comprised of the first letter of the hurricane that felled the tree, followed by the block number. Tree species were Guarea guidonia (Meliaceae) and Dacryodes excelsa (Burseraceae) but tree species were found to be similar and were not part of the model. Decay class was rated based on description of the logs were selected for study according to the classification of Torres (1994) [38]. Decay rate was classified 18 and 27 years after Hurricane Georges and Hugo, respectively: slow—retaining some bark, diameter loss less than $5 \mathrm{~cm}$; moderate-no bark remaining, diameter loss more than $5 \mathrm{~cm}$ but wood remaining; fast—either in the form of a mound of humus invaded by roots or no visible remains). Slope (\%) was measured where the logs were located.

\begin{tabular}{cccccccc}
\hline Location & Label & Hurricane & $\begin{array}{c}\text { Tree } \\
\text { Species }\end{array}$ & $\begin{array}{c}\text { Diam. } \\
\text { (cm) }\end{array}$ & $\begin{array}{c}\text { Decay } \\
\text { Class }\end{array}$ & $\begin{array}{c}\text { Decay } \\
\text { Rate }\end{array}$ & $\begin{array}{c}\text { Slope } \\
(\%)\end{array}$ \\
\hline Q. Sonadora & H.1 & Hugo 1989 & G. guidonia & $35-55$ & 2 & Slow & 28 \\
Q. Sonadora & G.1 & Georges 1998 & G. guidonia & $38-80$ & 1 & Slow & 35 \\
Q. Prieta, LFDP cell 02.09 & H.2 & Hugo 1989 & D. excelsa & $35-52$ & 3 & Fast & 35 \\
Q. Prieta, LFDP cell 07.10 & G.2 & Georges 1998 & D. excelsa & $30-35$ & 2 & Fast & 40 \\
Q. Sonadora & H.3 & Hugo 1989 & D. excelsa & $30-43$ & 2 & Moderate & 20 \\
Q. Sonadora & G.3 & Georges 1998 & D. excelsa & $30-55$ & 1 & Slow & 40 \\
LFDP cell 10.16 & H.4 & Hugo 1989 & G. guidonia & $39-53$ & 3 & Fast & 25 \\
LFDP cell 10.15 & G.4 & Georges 1998 & G. guidonia & $45-70$ & 2 & Fast & 25 \\
\hline
\end{tabular}

\subsection{Soil Sampling and Analysis}

\subsubsection{Soil Sampling}

Volumetric soil cores $(8 \times 8 \mathrm{~cm})$ were extracted to $10 \mathrm{~cm}$ depth using a two-part aluminum corer as shown in Figure 2. Soil cores were extracted from under logs by digging an approach trench and driving the rectangular corer in horizontally (Figure 2). Each core from under a log was spatially and temporally paired with a core extracted vertically and located $20-50 \mathrm{~cm}$ from the first core and away from the log. These are hence referred to as "under" and "away" positions. On each sample date, one pair of cores was extracted from each log on the uphill side of the hill slope, and a second pair was extracted on the downhill side of the same log to balance the effects of the logs acting as debris dams on steep slopes [9,35] (Figure 2). Samples were not pooled. 


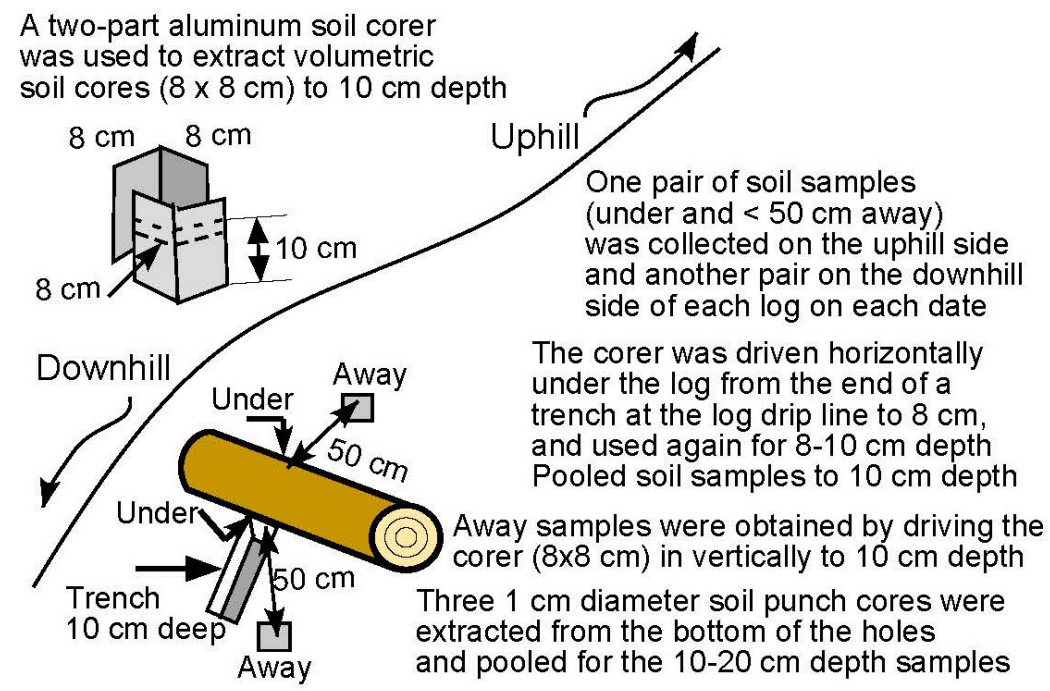

Figure 2. A rectangular, 2-part soil corer was driven into the soil horizontally from the end of an approach trench to obtain volumetric soil samples from 0 to $10 \mathrm{~cm}$ depth under logs. Corer halves were used twice $(0-8$ and $8-10 \mathrm{~cm})$ to obtain soil to $10 \mathrm{~cm}$ depth. Paired samples taken away from the logs were extracted vertically and located $20-50 \mathrm{~cm}$ away from the under-log core. Two pairs of cores were extracted on each date, one pair on the uphill side and the other on the downhill side of the log. Paired sample locations were randomly selected on each side of the log except for avoiding previously cored areas and large rocks. Soil samples from the 10-20 cm depth were extracted from the bottom of the first core holes using a punch corer.

There were three sampling times: April to early May 1999 (dry season); January 2000 (late wet season) and September 2000 (mid-wet season). These times corresponded to 0.6, 1.4 and 2 years after Hurricane Georges, and 9.5, 10.4 and 11 years after Hurricane Hugo, respectively. Samples in the same block were collected on the same day, and all samples for a particular time were collected within a 12-day period.

\subsubsection{Soil Nitrogen and Carbon Content}

Soil samples were weighed, hand-sorted to separate soil, roots and rocks; the roots and rocks were then weighed. A 15-20 g subsample was weighed into an aluminum pan, oven dried at $40{ }^{\circ} \mathrm{C}$ and re-weighed to determine soil \% moisture. Remaining soil was air dried and stored, then oven dried at $65{ }^{\circ} \mathrm{C}$. Total percent soil $\mathrm{C}$ and $\mathrm{N}$ were determined at the United States Forest Service (USFS) International Institute of Tropical Forestry laboratory using a LECO-2000 CNS analyzer [39] following the procedure of Vitousek and Matson [40]. Two samples of fresh bark beetle frass were also collected from different logs and analyzed for $\mathrm{C}$ and $\mathrm{N}$ using the CNS analyzer. We were unable to analyze the ammonium and nitrate we had extracted with $\mathrm{KCl}$ from fresh soils because of hurricane damage to facilities and infrastructure caused by Hurricane Georges.

\subsubsection{Soil Biota}

Root length was used as an indicator of resource hotspots. Roots were separated into coarse ( $>2 \mathrm{~mm}$ diameter) and fine (up to $2 \mathrm{~mm}$ diameter) from the $0-10 \mathrm{~cm}$ depth core samples, weighed and cut into ca. $1 \mathrm{~cm}$ long pieces. The decision to estimate root length was made after the first core (G.2) was processed, so those data are missing. Estimates of root lengths were made from three weighed subsamples per sample using the line-intercept method of Newmann [41]. Total root length was estimated by multiplying the mean root length per $g$ of roots by the total weight of the roots. Analyses were made on total root length (fine plus coarse) as coarse roots were negligible. 
Soil microbial biomass $C$ was estimated using the chloroform fumigation-incubation method [36]. Soil moisture was adjusted if there was less than $55 \%$ field capacity in two $30-40 \mathrm{~g}$ subsamples the day after collection. One of the subsamples from each sample was fumigated with chloroform under vacuum, reinoculated with soil and incubated for 10 days in air-tight jars with $\mathrm{NaOH}$ for trapping the $\mathrm{CO}_{2}$ respired; the unfumigated control was also incubated with a $\mathrm{CO}_{2}$ trap. After 10 days, the amount of $\mathrm{CO}_{2}$ trapped in the $\mathrm{NaOH}$ solution was determined by titration with $\mathrm{HCl}$ using phenolphthalein indicator dye. $\mathrm{CO}_{2}$ in the $\mathrm{NaOH}$ stock solution was also determined using titration, and the amount subtracted from the total in the incubation traps. Respired $\mathrm{CO}_{2}$ in the controls was subtracted from that in the fumigated samples according to the formula in Jenkins and Powlson [36].

\subsection{Statistical Analyses}

The design was a repeated measures nested randomized complete block. Dependent variables (soil \% C, soil \% N, microbial biomass C, total root length and soil moisture at 0-10 cm depth) were analyzed separately using a Repeated Measures Analysis; the 10-20 cm depth was only sampled twice for $\% \mathrm{C}$ and $\% \mathrm{~N}$, so those data were analyzed separately as a Repeated Measures nested randomized complete block. The independent variables (fixed effects in the models) were hurricane, position (under versus away from logs), hillslope direction (uphill or downhill), and time after Hurricane Georges (0.6, 1.4 and 2 years). Random effects of logs were nested within hurricanes. Block 2 was omitted from the root length analysis because of missing data for log G.2. All statistical analyses were performed using SAS Institute (version 9.3, [42]) software for a generalized linear mixed model using the pseudo-likelihood estimation technique via PROC GLIMMIX. In all analyses, either the normal or lognormal distribution and an identity link function best fit the data. For $\% \mathrm{~N}$ and root length at $0-10 \mathrm{~cm}$, we had to add the groups = hillslope and groups = position option, respectively, to adjust for heterogeneity of variance. In all cases, the correlation between the repeated time was best fit by the unstructured covariance structure. Model selection was based on fit statistics using HQIC (see Table 3 in Results). All models used the Identity Link Function, and all possible interactions were included. No differences were found between tree species, so they were treated as replicates in all the analyses.

Pearson's Product Moment correlations were used to analyze relationships among root length, soil \% N, soil \% moisture and microbial biomass C. Analyses were performed in Excel. A backwards elimination multiple linear regression was performed on the April 1999 and September 2000 data from the $0-10 \mathrm{~cm}$ depth using SAS software [42] after determining that all the variables met assumptions of normality and homoscedasticity of variance. The dependent variable was total root length, and the independent variables were soil microbial C, soil \% moisture and soil \% $\mathrm{N}$.

Table 3. Summary of the best fit statistical analysis models and results. Probability annotations are as follows: suggestive-sug., $p<0.1{ }^{*} p<0.05$; ${ }^{* *} p<0.01 ;{ }^{* * *} p<0.001$.

\begin{tabular}{|c|c|c|}
\hline Variable (s) & Levels & Probability \\
\hline \multicolumn{3}{|l|}{$0-10 \mathrm{~cm}$ soil horizon } \\
\hline \multicolumn{3}{|c|}{$\begin{array}{l}\text { Carbon (total \%) Lognormal, Identity Link function, Repeated Measures GLIMMIX, } \\
\text { HQIC fit statistics, all possible interactions included in model (shown if significant) }\end{array}$} \\
\hline Position (Under vs. Away) & 2 & $0.0324 *$ \\
\hline Hurricane within Block (Hugo vs. Georges) & 2 & 0.3264 \\
\hline Hillslope direction (Upslope vs. Downslope) & 2 & 0.8188 \\
\hline Time $(0.6,1.4$ and 2 years post-Georges) & 3 & $0.0374 *$ \\
\hline Block (log number, Hurricane nested within Block) true replicates & 4 & \\
\hline
\end{tabular}


Table 3. Cont.

\begin{tabular}{|c|c|c|}
\hline Variable (s) & Levels & Probability \\
\hline \multicolumn{3}{|c|}{$\begin{array}{l}\text { Nitrogen (total \%) Lognormal, Identity Link function, Repeated Measures GLIMMIX, } \\
\text { HQIC fit statistics, all possible interactions included in model (shown if significant) }\end{array}$} \\
\hline Position (Under vs. Away) & 2 & $0.0020 * *$ \\
\hline Hurricane within Block (Hugo vs. Georges) & 2 & 0.2177 \\
\hline Hillslope direction (Upslope vs. Downslope) & 2 & $0.0420 *$ \\
\hline Time $(0.6,1.4$ and 2 years post-Georges) & 3 & 0.6816 \\
\hline Block (log number, Hurricane nested within Block) true replicates & 4 & \\
\hline \multicolumn{3}{|c|}{$\begin{array}{l}\text { Microbial biomass C (mg } \cdot \mathrm{kg}^{-1} \text { soil) Gaussian, Identity Link function, Repeated } \\
\text { Measures GLIMMIX, HQIC fit statistics, all possible interactions included } \\
\text { (shown if significant) }\end{array}$} \\
\hline Position (Under vs. Away) & 2 & 0.0840 sug. \\
\hline Hurricane within Block (Hugo vs. Georges) & 2 & 0.9038 \\
\hline Hillslope direction (Upslope vs. Downslope) & 2 & 0.8660 \\
\hline Time $(0.6,1.4$ and 2 years post-Georges $)$ & 3 & $<0.001^{* * *}$ \\
\hline Block (log number, Hurricane nested within Block) true replicates & 4 & \\
\hline \multicolumn{3}{|c|}{$\begin{array}{l}\text { Root length (total) Lognormal, Identity Link function, Repeated Measures GLIMMIX, } \\
\text { HQIC fit statistics, all possible interactions included (shown if significant) }\end{array}$} \\
\hline Position (Under vs. Away) & 2 & 0.9049 \\
\hline Hurricane within Block (Hugo vs. Georges) & 2 & $0.0440 *$ \\
\hline Hillslope direction (Upslope vs. Downslope) & 2 & $0.0250 *$ \\
\hline Time $(0.6,1.4$ and 2 years post-Georges) & 2 & $0.0182 *$ \\
\hline $\begin{array}{l}\text { Block (log number, Hurricane nested within Block) true replicates, } \\
\text { deleted one incomplete block }\end{array}$ & 3 & \\
\hline Position by Time interaction & $1 \mathrm{DF}$ & $0.0368 *$ \\
\hline \multicolumn{3}{|l|}{ 10-20 cm soil horizon } \\
\hline \multicolumn{3}{|c|}{$\begin{array}{l}\text { Carbon (total \%) Lognormal, Identity Link function, Repeated Measures GLIMMIX, } \\
\text { HQIC fit statistics, all possible interactions included (shown if significant) }\end{array}$} \\
\hline Position (Under vs. Away) & 2 & $0.0273 *$ \\
\hline Hurricane within Block (Hugo vs. Georges) & 2 & 0.5899 \\
\hline Hillslope direction (Upslope vs. Downslope) & 2 & 0.7656 \\
\hline Time (0.6, and 1.4 years post-Georges) & 2 & 0.1673 \\
\hline Block (log number, Hurricane nested within Block) true replicates & 4 & \\
\hline Hurricane by position interaction & & 0.0870 sug. \\
\hline \multicolumn{3}{|c|}{$\begin{array}{l}\text { Nitrogen (total \%) Lognormal, Identity Link function, Repeated Measures GLIMMIX, } \\
\text { HQIC fit statistics, all possible interactions included (shown if significant) }\end{array}$} \\
\hline Position (Under vs. Away) & 2 & $0.0188 *$ \\
\hline Hurricane within Block (Hugo vs. Georges) & 2 & 0.7820 \\
\hline Hillslope direction (Upslope vs. Downslope) & 2 & 0.8711 \\
\hline Time ( 0.6 , and 1.4 years post-Georges) & 2 & 0.0579 sug. \\
\hline Block (log number, Hurricane nested within Block) true replicates & 4 & \\
\hline
\end{tabular}

\section{Results}

\subsection{Soil Nitrogen and Carbon}

Soil C and N were higher under than away from logs of both hurricanes (the 1989 and 1998 cohorts; Figure 3) and hurricane did not contribute significantly to these models (Table 3). All of the $\mathrm{C}$ and $\mathrm{N}$ analysis models used a Lognormal distribution and an identity link function based on best fit statistics (Table 3). Significant differences in both $\mathrm{C}$ and $\mathrm{N}$ concentration (\%) were found between 
under and away from log positions at the $0-10$ and 10-20 $\mathrm{cm}$ depths (Table 3). Hillslope direction (upslope versus downslope) was not significant except for soil \% $\mathrm{N}$ at the $0-10 \mathrm{~cm}$ depth; $\mathrm{N}$ was higher on the upslope side. In most comparisons within logs on a given date, mean $\mathrm{C}$ and $\mathrm{N}$ (mean of upslope and downslope) were higher under than away from the logs (Figure 3). Percent soil C and $\mathrm{N}$ differed significantly among sample dates, but only at the $0-10 \mathrm{~cm}$ depth (Table 3 ).
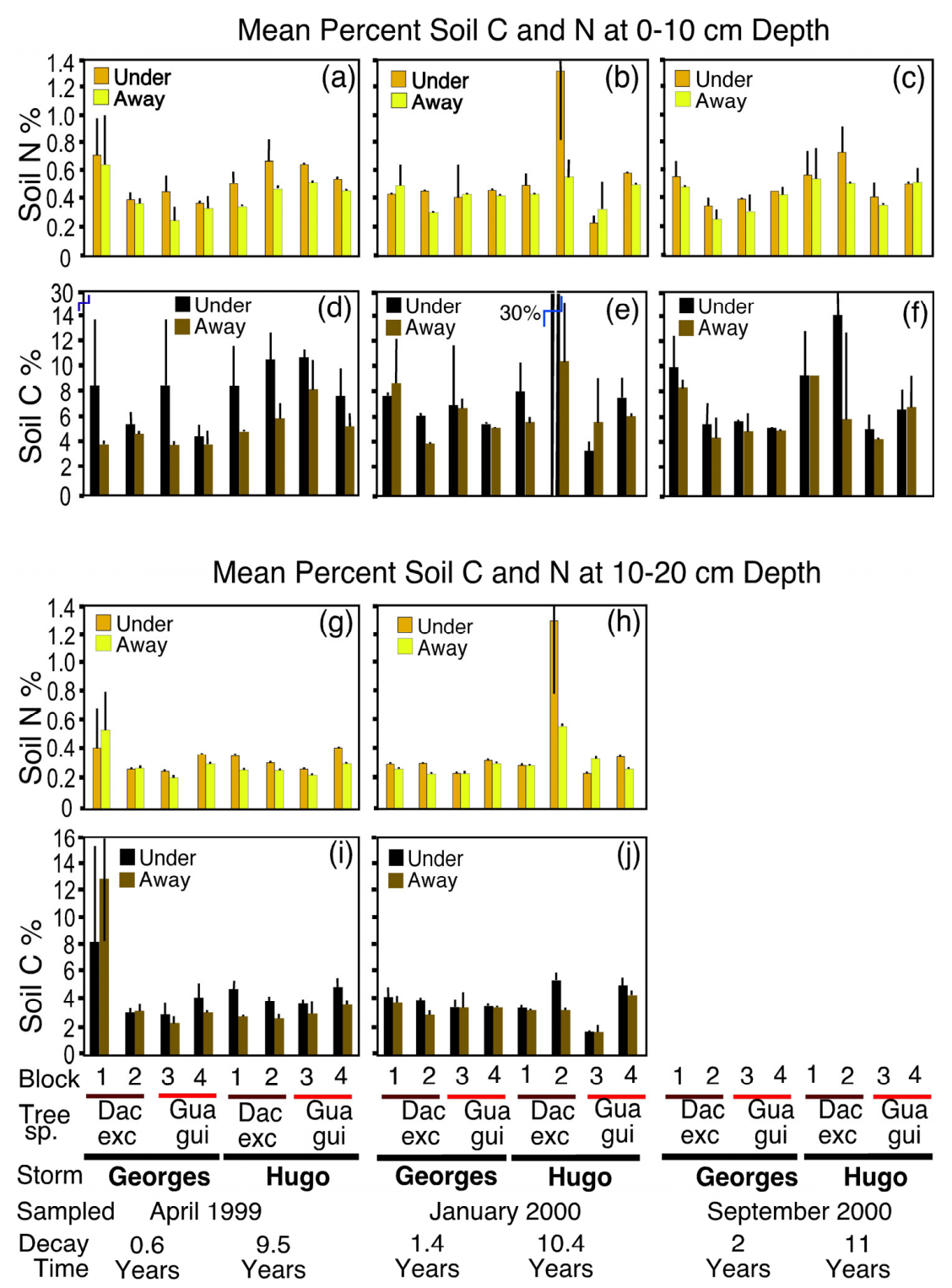

Figure 3. Mean percent soil $\mathrm{C}$ and $\mathrm{N}$ are presented for paired samples taken under decomposing logs (darker bars) versus samples taken $20-50 \mathrm{~cm}$ away and not under the logs (lighter bars) 0.6-2 and 9.5-11 years after Hurricanes Georges and Hugo, respectively. Tree species abbreviations are: Dac exc-Dacryodes excelsa, and Gua gui-Guarea guidonia. Data are means of two samples, one taken in the upslope direction and the other taken in the downslope direction on the same day (SD bars in black). April 1999 sampling was during the dry season, January 2000 was the end of the wet season, and September 2000 was during the wet season. (a-c) Mean soil \% N at 0-10 cm depth; (d-f) Mean soil $\%$ C at 0-10 cm depth; (g,h) Mean soil \% N at 10-20 cm depth; $(\mathbf{i}, \mathbf{j})$ Mean soil \% C at 10-20 cm depth.

Fresh Scoletid beetle frass C and N collected from Tabebuia heterophylla (DC.) Britton were $45.0 \%$ and $0.4 \%$, respectively, while frass from Mangifera indica L. contained $41.8 \% \mathrm{C}$ and $1.4 \%$. Thus, the C:N ratios were 128.4 for Tabebuia and 30.3 for Mangifera. 


\subsection{Soil Biota}

\subsubsection{Soil Microbial Biomass C}

The best fit model for soil microbial biomass $C$ was a Gaussian distribution and an identity link function. Differences in soil microbial biomass $C$ were only suggestive between positions (Table 3). Mean microbial biomass $C$ was generally higher under than away from logs, especially in the April 1999 dry season and January 2000 wet season samples (Figure 4) but there were no significant interactions of position with time (position time $p=0.634$; position time hurricane $p=0.268$ ). Differences in microbial $C$ were significant among sampling dates (Table 3). Microbial biomass $C$ was lower during the April 1999 dry season when soils were drier than in the two wet season samples (January and September 2000; Figure 4).

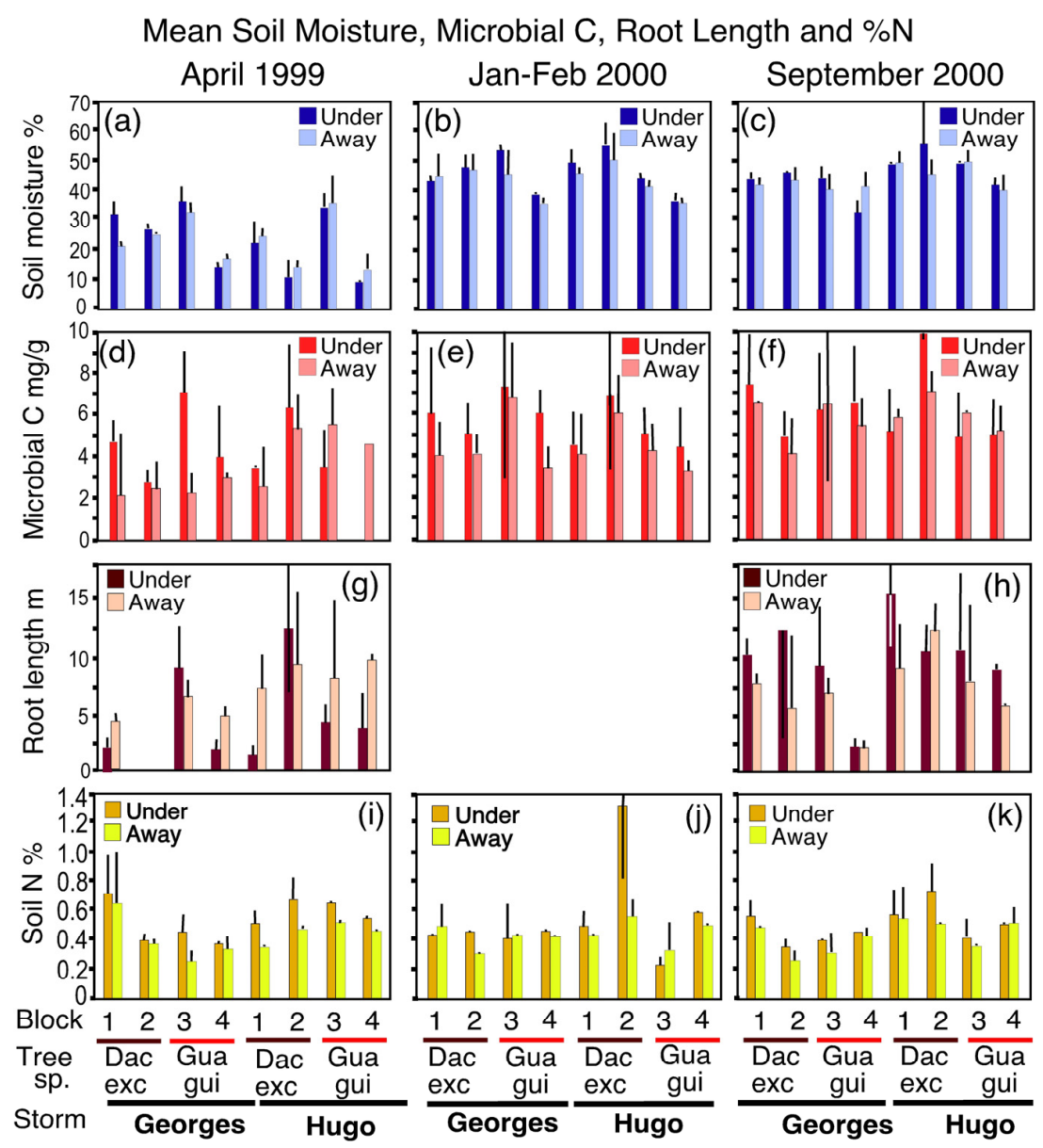

Figure 4. Mean soil \% moisture, microbial biomass $C$, total root length and soil \% $\mathrm{N}$ are presented for paired $(8 \times 8 \mathrm{~cm})$ soil cores taken to $10 \mathrm{~cm}$ depth under decomposing logs (darker bars) versus samples taken $20-50 \mathrm{~cm}$ away and not under the logs (lighter bars). April 1999 sampling was during the dry season, 0.6 and 9.5 years after Hurricane Georges and Hugo, respectively. January 2000 was the end of the wet season, 1.4 and 10.4 years after Hurricanes Georges and Hugo, respectively. September 2000 was during the wet season 2 and 11 years after Hurricanes Georges and Hugo, respectively. Data are means of two samples, one taken in the upslope direction and the other taken in the downslope direction on the same day (SD bars in black). Tree species abbreviations are: Dac exc-Dacryodes excelsa, and Gua gui-Guarea guidonia. One log from each hurricane (Georges 1998) and Hugo (1989) is within each of the four blocks. $(\mathbf{a}-\mathbf{c})$ : Mean soil \% moisture; $(\mathbf{d}-\mathbf{f})$ : Mean microbial biomass $\mathrm{C} ;(\mathbf{g}, \mathbf{h})$ : Mean $\mathrm{m}$ root length; (i-k): Mean soil \% N. 


\subsubsection{Roots}

Most of the tree roots were magnoliod (coarse, little-branched, hairless roots) in which the finest roots ranged from 1 to $2 \mathrm{~mm}$ diameter. The best fit model for the data was a Lognormal distribution and an identity link function. There was a significant time by position interaction (Table 3). Root length was greater away from the logs in the April dry season, and greater under the logs in the September wet season samples (Figures 4 and 5). Hurricane was significant (Table 3) as root length was greater for older logs from the Hurricane Hugo cohort than for younger logs from the Hurricane Georges cohort (Figure 4 and comparison of Least Square Means). Although hillslope direction was also significant (Table 3), and a comparison of Least Square Means showed significantly higher root length on the upslope than the downslope side of the logs, the pattern is not readily apparent in Figures 4 and 5 because of the reversal of rooting patterns by position between the dry and rainy seasons.

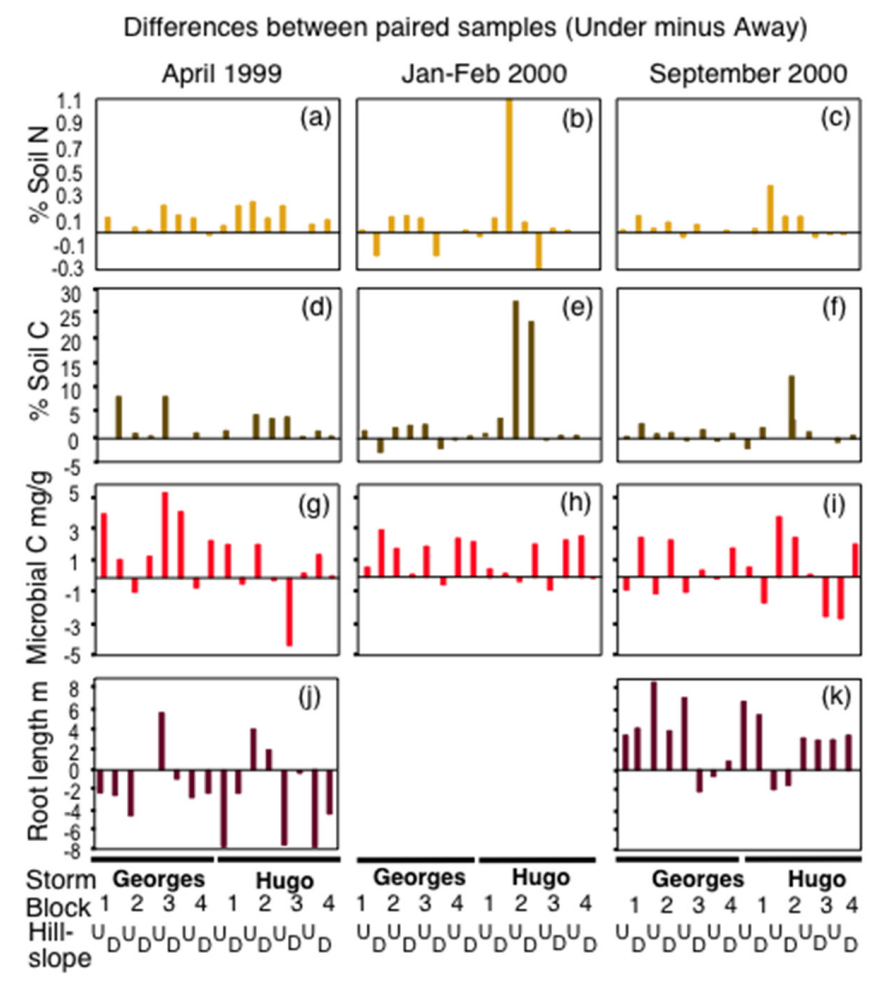

Figure 5. Percent soil N and C, microbial biomass $C$, and total root length are presented as differences in values between paired $(8 \times 8) \mathrm{cm}$ soil cores taken to $10 \mathrm{~cm}$ depth under decomposing logs minus values for samples taken $20-50 \mathrm{~cm}$ away and not under the logs. Thus, bars above the zero line had greater values under than away from the log within a pair while bars below the line had lower values under than away from the log. Bars represent a single pair of samples, one pair taken in the upslope direction (Hillslope $U$ ) and the other pair taken in the downslope direction (Hillslope D) on the same day. Logs fell in either Hurricane Hugo (1989) or Hurricane Georges (1998). Two logs, one from each hurricane, were represented in each of the four blocks. April 1999 sampling was during the dry season, 0.6 and 9.5 years after Hurricane Georges and Hugo, respectively. January 2000 was the end of the wet season, 1.4 and 10.4 years after Hurricanes Georges and Hugo, respectively. September 2000 was during the wet season 2 and 11 years after Hurricanes Georges and Hugo, respectively. (a-c) Difference (under-away) in soil \% N; (d-f) Difference (under-away) in soil \% C; (g-i) Difference (under-away) in microbial biomass $C_{;}(\mathbf{j}, \mathbf{k})$ : Difference (under-away) in $\mathrm{m}$ total root length.

\subsection{Soil Moisture}

Soil moisture only differed significantly between seasons $(p<0.0001)$. No differences were found between under versus away positions or for the interaction between season and position. Soils were significantly drier in the April dry season than in the two wet season samples (Figure 4). 


\subsection{Correlations among Variables}

Root length was most strongly correlated with microbial biomass $(R=0.36)$. The relationships between root length, soil \% $\mathrm{N}$ and microbial biomass $\mathrm{C}$ are shown in Figure 4. Root length was significantly positively correlated with soil microbial C $(R=0.36)$, soil moisture $(R=0.27)$ and soil \% $\mathrm{N}(R=0.18)$, and all the variables were significantly positively correlated with each other $(p<0.05)$. It was therefore surprising that the best multiple linear regression model (highest adjusted $R^{2}$ of 0.12 ; $p=0.016$ ) included all three variables, and the coefficient for microbial $\mathrm{C}$ changed from positive in the simpler models to negative because of the inverse relationship between root length and microbial $C$ in the April dry season samples (Figures 4 and 5). Microbial biomass $C$ was significantly positively correlated with soil moisture $(R=0.47)$ and $\% \mathrm{~N}(R=0.27)$.

\section{Discussion}

\subsection{Do Tree Roots Proliferate in Resource Hotspots?}

Decaying CWD has been found to either augment soil nutrient content or availability through inputs of leachates, insect frass and decayed wood [1,2,4-7,17], or conversely, to diminish available nutrients though responses of soil microbial communities to inputs of decay products with high C:N ratios $[18,19,21]$. The question of how tree roots respond to nutrient hotspots or local nutrient sinks created by CWD has received less attention [43], though decayed wood itself has been shown to provide an important source of moisture and nutrients for tree roots [3,6,43]. Trees respond readily to patches that contain limiting resources by proliferating fine roots disproportionately in resource hotspots [8,10-14]. Nutrient hotspots associated with CWD may thus play a critical role in maintaining forest productivity [12]. In this study, we used closely paired soil samples taken under and away from decaying logs belonging to two hurricane cohorts to determine if soil nitrogen, carbon, moisture, microbial biomass and tree root lengths were higher or lower under the CWD. Further, we examined whether the patterns of soil N, C and moisture changed through time and season, and whether roots proliferated more in patches with high nitrogen or moisture, and whether roots avoided soil patches with high microbial biomass since microbes can compete with roots for limiting nutrients [21].

\subsection{Effects on Soil Nitrogen and Carbon}

Unlike the studies by Zalamea et al. [22] and Bantle et al. [1,2], we did not find differences in soil $\% \mathrm{C}$ or $\% \mathrm{~N}$ between tree species. One of our tree species was shared with the Zalamea et al. study (D. excelsa) while our G. guidonia is in the same family and is nearly indistinguishable in quality from S. macrophylla that was used in Zalamea et al. [22,23]. Fresh wood of D. excelsa and S. macrophylla (and presumably, G. guidonia) has similar N concentrations [22]. Sites and species were confounded in the Zalamea et al. study [22], and while they included soil characteristics as covariates in their ANOVAs to remove effects due to differences between their two sites; it is possible that not all of the site soil differences were accounted for and that differences in clay content may have contributed to what was attributed to differences in tree species. In our study, three of the four blocks were located on the same soil type and all were at the same field site. We found significantly higher \% C under than away from logs at both depths $(0-10$ and $10-20 \mathrm{~cm})$ and at all sample times. However, the subsequent study by Zalamea et al. [22,23] 7 and 15 years after Hurricanes Hugo and Georges did not find any differences between under and away positions in soil \% C at $0-5 \mathrm{~cm}$ depth in the same forest type located at a different site on the eastern side of the Luquillo Mountains. Clay content is generally well correlated with soil organic C (SOC) [44] and the clay contents of soils in the Zalamea et al. [22] sites (Bisley and Río Chiquito) were lower than at our El Verde site (20\%-22\% versus 30\%-55\%). In addition, the soils in the Zalamea et al. study [22,23] were collected only to $5 \mathrm{~cm}$ depth; surface soils contain less clay and are also more influenced by inputs of organic matter from leaf litter than are deeper soil horizons. We therefore think that differences in sampling depth and clay content can explain the disparity between our results and those of Zalamea et al. [22,23]. Clay mineralogy is also an important 
determinant of SOC [44], but all of the highly weathered soils in both the Zalamea et al. [22,23] and this study were high in aluminum and iron [33]. Zinn et al. [45] noted that aluminum and iron cations are the most important interlayer mineral binders of dissolved organic matter (DOM), and Kaiser and Guggenberger [46] showed sorption to the mineral matrix strongly preserved DOM. In contrast, Kayahara et al. [47] did not find greater amounts of organically complexed $\mathrm{Fe}$ and $\mathrm{Al}$ in soils below forest floors with woody debris versus those without wood in the boreal forest of British Colombia despite finding more total $C$ and greater $C$ in the humic, fulvic and polyphenol fractions of the overlying forest floors containing wood.

While we do not know how stable the $\mathrm{C}$ originating from our logs is and thus how much the logs contribute to $C$ sequestration in soils, Kalbitz et al. [48] showed that sorption of recalcitrant compounds was four times greater than labile compounds. Interestingly, one of our logs (H.2) showed high \% C (14\%-33\% at $0-10 \mathrm{~cm}$ depth on two of the three sample dates and $4.7 \%$ at $10-20 \mathrm{~cm}$ depth in January 2000 , and \% C was also high away from the log in one of the two January 2000 samples. Log H.2 was D. excelsa, a species that had historically been used in the El Verde Research Area for making charcoal, so we suspected this log fell onto an old charcoal pit. Soils around the marked log were examined for charcoal, which is known to cause elevated soil C, but none was found. We therefore postulate instead that the paired cores collected in January and September of 2000 from log H.2 coincided with the C imprint of a previously decomposed log whereas the April 1999 core samples did not. The highest \% C values in the upper $10 \mathrm{~cm}$ of soil both under and away from log H.2 in January 2000 corresponded to our lowest soil bulk density measurements, which suggests an abundance of light fraction soil $\mathrm{C}$. Log G.1 also had remarkably high soil \% C and \% N, but primarily at the lower, $10-20 \mathrm{~cm}$ depth. This suggests that the legacy of the former decaying log near G.1 dated earlier than the legacy of the decayed $\log$ associated with H.2, and that light fraction C in the surface soil near G.1 was lost through decomposition and leaching. Our data indicate that $20 \%$ of randomly placed soil cores at our site may fall on $\mathrm{C}$ and $\mathrm{N}$-rich hotspots that are the legacy of decomposed prior CWD. Consistent with our results, Gutiérrez del Arroyo and Silver [49] found that ten years after a simulated hurricane debris addition experiment at our site, soil $\mathrm{C}$ and $\mathrm{N}$ were elevated relative to control plots in both surface and deep soils, and that both light fraction organic matter and organic molecules complexed with minerals in the heavy soil fractions were elevated. Both Harmon et al. [3] and Spears et al. [20] noted difficulty in detecting effects of decaying logs on the underlying soil in Oregon in northwestern USA, likely because of overlapping legacies from previously decomposed CWD. The fast rates of CWD decomposition at our wet tropical site (Table 2) and wet tropical forests in general [24] are probably correlated with fast rates of carbon loss belowground, which makes the imprint of prior treefalls on soil $\mathrm{C}$ and $\mathrm{N}$ in our forest clearer than in the cool temperate forests of Oregon with slower decomposition [3,20].

Our finding of more $C$ under logs only 0.6 years after Hurricane Georges under logs from Georges was surprising as little decomposition was observed. Furthermore, we did not find significant differences in $\% \mathrm{C}$ in soils beneath logs from two different hurricane cohorts spaced 9 years apart. However, Bantle et al. [1] found concentrations of dissolved organic C (DOC) were 5-10 times higher in runoff from logs than in throughfall even during early decomposition in a temperate beech forest (3 year-old logs). The products of fungal white rot in wood are primarily $\mathrm{CO}_{2}$ and DOC [34]. Zalamea et al. [23] found significantly more water-soluble organic matter under than away from their decomposing logs, consistent with DOC of Bantle et al. [1], despite finding no differences in total soil C.

We found a significant effect of season on soil \% $\mathrm{C}$ at $0-10 \mathrm{~cm}$ depth, with increases in the dry season (see graphical abstract). Turner et al. [50] found a similar increase in soil C during the dry season in a more strongly seasonal forest on Barro Colorado Island in Panama. However, we did not observe a significant increase in soil $\mathrm{N}$ whereas the study in Panama did [50].

Much of the early $\mathrm{C}$ and $\mathrm{N}$ inputs to soil from fallen logs in Puerto Rico may come from bark beetle frass $[21,38,51]$, and large deposits of frass were noted under our Georges logs beginning 5 months after they had fallen. We also found especially high microbial biomass $\mathrm{C}$ in addition to higher $\mathrm{C}$ and $\mathrm{N}$ 
under versus away from Georges logs in that sampling (Figure 5). The few studies on the ecological roles of bark beetles, and effects of xylophagous beetle frass on nutrient cycling $[4,5,7,51]$ indicate rapid decay of the inner bark, which contains the highest concentration of nitrogen. Showalter [4] showed rapid loss of inner bark in hardwood logs was related to invertebrate activity and was independent of climate across a broad geographic gradient in North America. Similar to our study, in Australia, Lindsay and Cunningham [16] and Goldin and Hutchinson [17] found significantly higher C, N and $P$ in soil near logs than $80 \mathrm{~cm}$ away. Also consistent with our observations, Cobb et al. [51] found in boreal forest of Canada that xylophagous beetles in a conifer forest that had burned followed by salvage logging had significantly increased soil $\mathrm{C}$ and $\mathrm{N}$ at the bases of dead trees via frass and chewing debris, and a positive and significant relationship between larval abundance and total soil N, presumably due to inputs of frass. They also found that addition of these beetle frass and chewings to soil increase microbial respiration by more than three-fold; furthermore, frass additions decreased germination of two of their three test plant species (as most of the nitrogen returned via frass is immobilized by microbial biomass and is thus not immediately available to plants). There are two mechanisms by which saproxylic organisms can affect $\mathrm{N}$ release as decomposition proceeds. They can accelerate release of $\mathrm{N}$ immobilized in microbial biomass through indirect interactions with cord-forming fungi $[52,53]$. They can also promote $\mathrm{N}_{2}$ fixation by providing conditions conducive to prokaryote activity in their guts as well as in comminuted wood [54]. Results from Asmus [55] suggest that frass maybe a preferred substrate for $\mathrm{N}_{2}$ fixing bacteria. Thus, our findings contribute to a greater understanding of the potential effects of CWD on soil carbon and nutrient cycling following both natural and anthropogenic forest disturbances.

Further contributing to early impacts of logs on soil nutrient cycling, wood decomposes more quickly in tropical forests [24,25] such as the one at El Verde in Puerto Rico than in temperate forest studied by Bantle et al. [1]. Three of our four logs in blocks 2 and 4 could only be identified by the pink-tipped poles marking their drip lines at both ends of the logs and the fourth log was reduced to a $2 \mathrm{~cm}$ deep humus deposit with roots after 18 and 27 years of decomposition for Georges and Hugo cohorts, respectively. These CWD turynover times are consistent with those from elsewhere in the neotropics [24,25]. Lang and Knight [56] proposed a faster wood decomposition in the tropics than in temperate zones because a warm and humid forest floor in the tropics would favor invertebrate activity through the year. In contrast, Torres $[38,57]$ argued that high moisture content, the cool temperatures (caused by cloud cover, rainfall and winds) and a low animal diversity on the logs in the wet forest in Puerto Rico seem to retard wood decay in this habitat. Here, we argue that hurricane conditions can significantly alter both abiotic (changes in light and moisture level conditions) and biotic conditions that can affect the rate of recovery and nutrient cycling in the forest via decomposition processes [58]. Our observations in this study would support the contention that dry exposed wood generated by hurricane disturbance favors saproxylic species [57], which in turn can initiate the decay process. It has been suggested that wood comminution and bark fragmentation caused by these organisms might have increased nutrient loss through leaching [59,60].

Our finding of significantly higher $\% \mathrm{~N}$ in soils at two depths under than away from logs is concordant with the pattern of $\% \mathrm{C}$, which is not surprising as soil $\mathrm{C}$ and $\mathrm{N}$ are usually correlated and $\mathrm{C}$ and $\mathrm{N}$ mineralization are coupled [61,62]. Bantle et al. [2] found a net release of $\mathrm{N}$ from decaying beech logs during early decomposition in temperate forest in Germany, with the largest component being dissolved organic $\mathrm{N}$ (DON). Hillslope direction was also significant for the $0-10 \mathrm{~cm}$ depth, with $\% \mathrm{~N}$ (but not $\% \mathrm{C}$ ) being higher on the upslope side of the logs. This result is consistent with logs acting as terrestrial debris dams that trap leaf litter on their upslope side [9,35], especially in April 1999 and January 2000 (Figure 5a,b). The dates with high surface soil \% N coincide with peaks in leaf litterfall in our site [63]. Tropical forest leaf litter at El Verde in Puerto Rico has high concentrations of N (1\% in González et al. and Silver et al. [64,65]; $1.5 \%$ in Lodge et al. [66]) relative to temperate coniferous forest litter, as is typical of wet lowland and low elevation montane tropical forests, and net mineralization usually begins immediately and proceeds steadily rather than being preceded by 
immobilization phase in the litter during decomposition [67,68]. It is thus not surprising that soil \% $\mathrm{N}$ was higher in the upper soil horizon on the upslope side of our logs.

\subsection{Effects on Biota}

\subsubsection{Root Responses}

Root length was greater away from the logs during the April dry season, but the pattern reversed in the September wet season leading to a significant time by position interaction. Although the shifting of roots away from soil under logs in the dry season corresponds to when soil microbial biomass $C$ was highest under logs, this might be interpreted as competitive exclusion of roots for nutrients by soil microbial biomass, the correlation between roots and soil microbial biomass $C$ was modest $(R=0.36)$. The correlation between root length and soil moisture was higher $(R=0.47)$ while the correlation with soil \% $\mathrm{N}$ was smaller (0.18); the correlation of microbial $\mathrm{C}$ with soil \% moisture $(R=0.47)$ was higher than with soil \% $\mathrm{N}(R=0.27)$. The change in the microbial $C$ coefficient from positive to negative in the best-fit multiple linear regression model that included all independent variables was informative and consistent with the inverse relationship between microbial $C$ and root length in the 0.6 year dry season samples from Georges logs. These patterns are consistent with root proliferation where nutrients were more available. On the other hand, mean root length was higher under than away from logs whereas mean soil microbial biomass $C$ did not differ between positions in September (wet season), which is not consistent with the competitive exclusion hypothesis. However, inputs of bark beetle frass were greatest during the first sampling in the dry season, so the inverse correlation between roots and microbial $C$ in the dry season may be related to effects of early frass deposition. Root lengths were also significantly higher on the upslope sides of logs, concordant with significantly higher $\% \mathrm{~N}$ on the upslope side in the upper $10 \mathrm{~cm}$ of soil, suggesting that roots may proliferate where $\mathrm{N}$ is more available. Availability of other nutrients, such as $\mathrm{P}$, may have contributed to the rooting patterns since $\% \mathrm{~N}$ is correlated with \% C, and C is known to increase P-availability in weathered tropical clay soils [26]. Soil moisture is another resource that can increase root proliferation [3,43]. Although soil moisture was slightly higher under than away from Georges cohort logs in the dry season and the January 2000 wet season sampling (Figures 4 and 5), the differences were slight. One of the lowest soil moistures was recorded for a Hugo log in Block 2 (Figure 4a), which corresponded to some of the highest root lengths; this pattern is not consistent with moisture being a limiting resource that determines root proliferation. Soil microbial $\mathrm{C}$ and soil $\% \mathrm{~N}$ were also high in those samples, so nutrient availability also may not have been limiting in the wet season under H.2. Competitive displacement can only occur where critical resources are limited.

\subsubsection{Soil Microbial Biomass Responses}

We found the strongest differences in soil microbial $C$ between seasons, with values being significantly lower during the April dry than in the two wet season samplings. The soil was so dry at the beginning of the April sampling that one soil sample did not lose weight on oven drying, and some of the others probably lost water of hydration rather than free water. Fungal biomass [68] and the microbial community $[69,70]$ in wet tropical forest of Puerto Rico were shown to be highly sensitive to drying, though community effects were most evident in the very driest soils.

Soil microbial biomass was often (suggestively) higher under than away from logs at the $0-10 \mathrm{~cm}$ depth, especially for Georges logs 0.6 years after the hurricane in the April dry season samples. This coincided with lower root lengths under than away from the Georges logs in the April dry season samples. Zalamea et al. [22] did not find differences in microbial biomass between positions, but they did not sample during the early stages of decomposition. Two possible mechanisms seem plausible for explaining this pattern: competition between microbial biomass and plant roots for limiting nutrients and allelophathic effects of beetle frass on roots. As noted above in the discussion of soil \% $\mathrm{C}$, the input of Scoletid beetle frass may have stimulated the soil microbial biomass immobilization of $\mathrm{N}$ that 
was observed by Zimmerman et al. [21] beginning 4-6 months after Hurricane Hugo. Cobb et al. [35] similarly found higher microbial activity with input of xylophagous beetle frass and chewings in temperate conifer forest. The C:N ratio of the beetle frass and chewings in the Cobb et al. [55] study was 84-55 while the Scoletid beetle frass we analyzed had C:N ratios of 30-128; all higher than ratios $>12-24$ that are associated with $\mathrm{N}$ immobilization [62,71]. Frass extracts of bark beetle larvae have been attributed to potent allelochemicals that might inhibit germination and seedling growth [72]. Thus, the results of our study would suggest a conservative mechanism of recovery and nutrient retention following a hurricane in this tropical forest that is similar to that observed in the boreal forest of Canada after post fire disturbance. The observation of greater root length away than underneath the decaying logs could potentially be explained by allochemical inhibition by secondary compounds contained in bark beetle frass on roots.

In addition to DOC contributions to soil $\mathrm{C}$ from bark and sapwood leachates, frass from bark beetles in the Scoletideae may have contributed to early increases in soil C below our logs. The fourth author recorded copious amounts of frass from Scoletid bark beetles underneath our recently fallen logs five months after Hurricane Georges. Our analyses of two representative samples of Scoletid beetle frass had $42 \%-45 \% \mathrm{C}$. Because Scoletid beetle frass has a fine texture resembling sawdust due to comminution by the beetles and processing in their guts and a high C:N ratio, it is likely to be decomposed quickly by fungi. Our observations of higher soil microbial biomass under than away from Georges logs 7 months after falling (Figure 5) are consistent with the $\mathrm{N}$ immobilization by soil microbial biomass and the slowing of forest canopy cover beginning 4-6 months after Hurricane Hugo found by Zimmerman et al. [21]. In a canopy trimming experiment conducted at our field site in El Verde, Silver (personal communication, 11 March 2014) found increases in soil respiration for several years after forest plots were subjected to a simulated hurricane as compared to control plots. Further, Xianbin Liu (personal communication, 12 January 2016) found more labile $C$ in soils of the hurricane simulation plots for at least 1.5 years after the second application of trimming. Thus, it is likely that at least some of the $\mathrm{C}$ originating from coarse woody debris from disturbances such as tropical cyclones is labile and readily decomposed once it reaches the soil and is not sequestered. This labile carbon, however, can contribute to microbial immobilization of nutrients, leading to temporarily lower nutrient availability for tree roots.

\section{Conclusions}

Tropical cyclonic storms, bark beetle outbreaks, fires and anthropogenic disturbances deposit CWD on forest floors, which significantly alters the soil C and $\mathrm{N}$ dynamics, and could potentially alter soil fertility and forest productivity. Decomposing logs from two hurricanes spaced 9 years apart left a significant signature on the underlying soil, even as early as 0.6 years after the trees fell. Percent soil $C$ and $N$ were significantly higher under than near logs at both $0-10$ and 10-20 cm depths at all sample times. Legacies of previously decomposed logs in the soil $\mathrm{C}$ and $\mathrm{N}$ were also detected. These signatures of decomposing logs on soil $\mathrm{C}$ and nutrients contribute to high spatial heterogeneity in soil characteristics, and lead to nutrient hotspots as well as sinks. The close spatial pairing $(<50 \mathrm{~cm}$ apart) of soil samples taken under and away from decomposing logs in this study was effective in reducing background variation sufficiently to detect the effects of the logs on soil $\mathrm{C}, \mathrm{N}$, microbial biomass $\mathrm{C}$ and roots, and was also comparable to root 'choice experiments'. Early increases in soil microbial $C$ under logs felled by Hurricane Georges were detected 0.6 years after the hurricane, and may have been stimulated by inputs of insect frass with high C:N ratios from Scoletid bark beetles in addition to leachates from bark and sapwood. The soils beneath the logs in these early, dry season samples may have been a nutrient sink caused by microbial nutrient immobilization. Correspondingly, roots were less abundant under the logs than away from the logs at that time. Soils on the upslope side of the logs differed only from the downslope side for soil $\% \mathrm{~N}$ and total root length in the upper $0-10 \mathrm{~cm}$, likely because of $\mathrm{N}$ fluxes from leaf litter accumulations on the upslope sides of logs on steep slopes and corresponding proliferation of fine roots where $\mathrm{N}$ was more available. This also indicates 
that root proliferation was tracking nutrient availability in transient hotspots. The longevity of the $C$ in soils originating from the decomposing logs was not determined, but spatial anomalies (hotspots) in some our samples suggest that higher soil $\mathrm{C}$ may persist after any remains of a decomposed log have disappeared. Evidence from other studies in the same area also suggest, however, that part of the soil $\mathrm{C}$ originating from coarse woody debris is labile and is respired quickly by soil microbial biomass as $\mathrm{CO}_{2}$. The proliferation of roots under decaying logs in the wet season but not the dry season highlights the importance of maintaining spatial heterogeneity in management of coarse woody debris following natural disturbances and logging plus salvage operations in order to allow tree roots to track and exploit nutrient and resource hotspots as they change through time.

Acknowledgments: This research was performed under grants DEB-0218039 and 1239764 from the National Science Foundation to the Institute of Tropical Ecosystem Studies, University of Puerto Rico, and the United States Department of Agriculture, Forest Service, International Institute of Tropical Forestry as part of the Long-Term Ecological Research Program in the Luquillo Experimental Forest. Additional support for G. González was provided by the Luquillo LCZO grant (EAR-1331841). We are thankful to Maria M. Rivera, Mary Jeane Sánchez, Maysaá Ittayem, Edwin Lopéz, Carmen Marrero, Marybelís Santiago and other staff at the International Institute of Tropical Forestry-Soil Laboratory who helped process soil samples; and Xiaoming Zou for advice on measuring soil microbial biomass. We thank the statistician for the United States Department of Agriculture, Forest Service, Northern Research Station, John Stanovick, for statistical analyses and review, and Walter Shortle and Tana Wood for pre-reviews that improved the manuscript. Additional support was provided by the University of Puerto Rico, Rio Piedras.

Author Contributions: D. Jean Lodge and Naomi Clum conceived designed the experiment, and Naomi Clum located the logs for this study and conducted the April 1999 sampling with help from D. Jean Lodge; D. Jean Lodge conducted the January 2000 sampling and Dirk Winter conducted the September 2000 sampling with assistance from D. Jean Lodge. Dirk Winter corrected the data sets and coordinated soil analyses. D. Jean Lodge, Dirk Winter and Grizelle González wrote the paper.

Conflicts of Interest: The first and third authors are United States Government Employees, and since this manuscript was prepared as part of their official duties, it is in the public domain and is not subject to copyright.

\section{References}

1. Bantle, A.; Borken, W.; Ellerbrock, R.H.; Schulze, E.D.; Weisser, W.W.; Matzner, E. Quantity and quality of dissolved organic carbon released from coarse woody debris of different tree species in the early phase of decomposition. For. Ecol. Manag. 2014, 329, 287-294. [CrossRef]

2. Bantle, A.; Borken, W.; Matzner, E. Dissolved nitrogen release from coarse woody debris of different tree species in the early phase of decomposition. For. Ecol. Manag. 2014, 334, 277-283. [CrossRef]

3. Harmon, M.E.; Franklin, J.F.; Swanson, F.J.; Sollins, P.; Gregory, S.V.; Lattin, J.D.; Anderson, N.H.; Cline, S.P.; Aumen, N.G.; Sedell, J.R.; et al. Ecology of coarse woody debris in temperate ecosystems. Adv. Ecol. Res. 1986, 15, 133-302.

4. Edmonds, R.L.; Eglitis, A. The role of Douglas-fir beetle and wood borers in the decomposition of and nutrient release from Douglas-fir logs. Can. J. For. Res. 1989, 19, 853-859. [CrossRef]

5. Schowalter, T.D. Heterogeneity and nutrient dynamics of oak (Quercus) logs during the first 2 years of decomposition. Can. J. For. Res. 1992, 22, 161-166. [CrossRef]

6. Stevens, V. The Ecological Role of Coarse Woody Debris: An Overview of the Ecological Importance CWD in BC Forests; Work Paper 30; British Columbia Ministry of Forests: Victoria, BC, Canada, 1997.

7. Ricker, M.C.; Graeme Lockaby, B.; Blosser, G.D.; Conner, W.H. Rapid wood decay and nutrient mineraliztion in an old-growth bottomland hardwood forest. Biogeochemistry 2016, 127, 323-338. [CrossRef]

8. Johnson, D.W.; Woodward, C.; Meadows, M.W. A three-dimensional view of nutrient hotspots in a Sierra Nevada forest soil. Soil Sci. Soc. Am. J. 2014, 78, S225-S236. [CrossRef]

9. Lodge, D.J.; McDowell, W.H.; Macy, J.; Ward, S.K.; Leisso, R.; Claudio Campos, K.; Kuhnert, K. Distribution and role of mat-forming saprobic basidiomycetes in a tropical forest. In Ecology of Saprobic Basidiomycetes; Boddy, L., Frankland, J.C., Eds.; Academic Press, Elsevier Ltd.: Amsterdam, The Netherlands, 2008; pp. 195-208.

10. Stewart, C.G. A test of nutrient limitation in two tropical montane forests using root ingrowth cores. Biotropica 2000, 32, 369-373. [CrossRef] 
11. Cuevas, E.; Medina, E. Nutrient dynamics within Amazonian forests. II. Fine root growth, nutrient availability, and leaf litter decomposition. Oecologia 1988, 76, 222-235. [CrossRef]

12. Haines, B. Impact of leaf-cutting ants on vegetation development at Barro Colorado Island. In Tropical Ecological Systems: Trends in Terrestrial and Aquatic Research; Golley, F.G., Medina, E., Eds.; Springer: New York, NY, USA, 1975; pp. 99-101.

13. Raich, J.W.; Riley, R.H.; Vitousek, P.M. Use of root-ingrowth cores to assess nutrient limitations in forest ecosystems. Can. J. For. Res. 1994, 24, 2135-2138. [CrossRef]

14. St. John, T.V.; Coleman, D.C.; Reid, C.P. Growth and spatial distribution of nutrient-absorbing organs: Selective exploitation of soil heterogeneity. Plant Soil 1983, 71, 487-493. [CrossRef]

15. Sayer, E.J.; Banin, L.F. Tree nutrient cycling in tropical forest-Lessons from fertilization experiments. In Tropical Tree Physiology: Adaptation and Responses in a Changing Environment; Goldstein, G., Santiago, L.S., Eds.; Tree Physiology Volume 6; Springer: New York, NY, USA, 2016; pp. 275-297.

16. Goldin, S.R.; Hutchinson, M.F. Coarse woody debris modifies surface soils of degraded temperate eucalypt woodlands. Plant Soil 2013, 370, 461-469. [CrossRef]

17. Lindsay, A.E.; Cunningham, S.A. Native grass establishment in grassy woodlands with nutrient-enriched soil and exotic grass invasion. Restor. Ecol. 2011, 19, 131-140. [CrossRef]

18. Hafner, S.D.; Groffman, P.M. Soil nitrogen cycling under litter and coarse woody debris in a mixed forest in New York State. Soil Biol. Biochem. 2005, 37, 2159-2162. [CrossRef]

19. Kwak, J.H.; Chang, S.X.; Naeth, M.A.; Schaaf, W. Coarse woody debris extract decreases nitrogen availability in two reclaimed oil sands soils in Canada. Ecol. Eng. 2015, 84, 13-21. [CrossRef]

20. Spears, J.D.H.; Holub, S.M.; Harmon, M.E.; Lajtha, K. The influence of decomposing logs on soil biology and nutrient cycling in an old-growth mixed coniferous forest in Oregon, USA. Can. J. For. Res. 2003, 33, 2193-2201. [CrossRef]

21. Zimmerman, J.K.; Pulliam, W.M.; Lodge, D.J.; Quiñones-Orfila, V.; Fetcher, N.; Guzman-Grajáles, S.; Parrotta, J.A.; Asbury, C.E.; Walker, L.R.; Waide, R.B. Nitrogen immobilization by decomposing woody debris and the recovery of tropical wet forest from hurricane damage. Oikos 1995, 72, 314-322. [CrossRef]

22. Zalamea, M.; González, G.; Lodge, D.J. Physical, chemical and biological properties of soil under decaying wood in a tropical wet forest in Puerto Rico. Forests 2016, 7, 168. [CrossRef]

23. Zalamea, M.; González, G.; Ping, C.L.; Michaelson, G. Soil organic matter dynamics under decaying Wood in a subtropical wet Forest: Effect of tree species and decay stage. Plant Soil 2007, 296, 173-185. [CrossRef]

24. Clark, D.B.; Clark, D.A.; Brown, S.; Oberbauer, S.F.; Veldkamp, E. Stocks and flows of coarse woody debris across a tropical rain forest nutrient and topography gradient. For. Ecol. Manag. 2002, 164, 237-248. [CrossRef]

25. Delaney, M.; Brown, S.; Lugo, A.E.; Torres-Lezama, A.; Quintero, N.B. The quantity and turnover of dead wood in permanent forest plots in six life zones of Venezuela. Biotropica 1998, 30, 2-11. [CrossRef]

26. Sanford, R.L., Jr.; Parton, W.J.; Ojima, D.S.; Lodge, D.J. Hurricane effects on soil organic matter dynamics and forest production in the Luquillo Experimental Forest, Puerto Rico: Results of simulation modeling. Biotropica 1991, 23, 364-372. [CrossRef]

27. Emanuel, K.A. Increasing destructiveness of tropical cyclones over the past 30 years. Nature 2005, 436, 686-688. [CrossRef] [PubMed]

28. Knutson, T.R.; McBride, J.L.; Chan, J.; Emanuel, K.; Holland, G.; Landsea, C.; Held, I.; Kossin, J.P.; Srivastava, A.K.; Sugi, M. Tropical cyclones and climate change. Nat. Geosci. 2010, 3, 157-163. [CrossRef]

29. Mei, W.; Xie, S.P. Intensification of landfalling typhoons over the northwest Pacific since the late 1970s. Nat. Geosci. 2016, 9, 753-757. [CrossRef]

30. Bentz, B. Climate Change and bark beetles of the western United States and Canada: Direct and indirect effects. Bioscience 2010, 60, 602-613. [CrossRef]

31. Dale, V.H.; Joyce, L.A.; McNulty, S.; Neilson, R.P.; Ayres, M.P.; Flannigan, M.D.; Hanson, P.J.; Irland, L.C.; Lugo, A.E.; Peterson, C.J.; et al. Climate change and forest disturbance. Bioscience 2001, 51, 723-734. [CrossRef]

32. Brown, S.; Lugo, A.E.; Silander, S.; Liegel, L. Research History and Opportunities in the Luquillo Experimental Forest; General Technical Report, SO-44; United States Forest Service: Washington, DC, USA, 1983.

33. Soil Survey Staff. Order 1 Soil Survey of the Luquillo Long-Term Ecological Research Grid, Puerto Rico; United States Department of Agriculture, National Resources Conservation Service: Lincoln, NE, USA, 1995. 
34. Lodge, D.J.; Cantrell, S.A.; González, G. Effects of canopy opening and debris deposition on fungal connectivity, phosphorus movement between litter cohorts and mass loss. For. Ecol. Manag. 2014, 332, 11-21. [CrossRef]

35. Shanley, J.B.; Lodge, D.J.; Krabbenhoft, D.P.; Olson, M.L.; McDowell, W.H. New and old mercury fluxes from mercury amendments to Puerto Rico soil columns. In Presented at the American Geophysical Union Fall 2008 Meetings, San Francisco, CA, USA, 15-19 December 2008; Available online: http:/ /adsabs.harvard. edu/abs/2008AGUFM.B13C0457S (accessed on 17 August 2009).

36. Jenkinson, D.S.; Powlson, D.S. The effects of biocidal treatments on metabolism in soil-V: A method for measuring soil biomass. Soil Biol. Biochem. 1976, 8, 209-213. [CrossRef]

37. Lin, Q.; Brookes, P.C. An evaluation of the substrate-induced respiration method. Soil Biol. Biochem. 1999, 31 , 1969-1983. [CrossRef]

38. Torres, J.A. Wood decomposition of Cyrilla racemiflora in a tropical montane forest. Biotropica 1994, 26, 124-140. [CrossRef]

39. Tabatabai, M.A.; Bremmer, J.M. Automated instruments for determination of total carbon, nitrogen, and sulfur in soils by combustion techniques. In Soil Analysis, Modern Instruments Techniques; Marcel Dekker, Inc.: New York, NY, USA, 1991; pp. 261-286.

40. Vitousek, P.M.; Matson, P.A. Mechanisms of nitrogen retention in forest ecosystems: A field experiment. Science 1984, 225, 51-52. [CrossRef] [PubMed]

41. Newmann, E.I. A method of estimating the total length of root in a sample. J. App. Ecol. 1966, 3, $139-145$. [CrossRef]

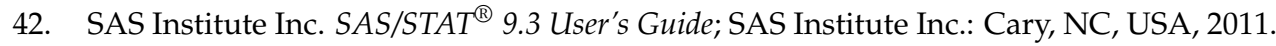

43. Harvey, A.E.; Jurgensen, M.F.; Larssen, M.J. Effects of Soil Organic Matter on Regeneration in Northern Rocky Mountain Forests; GTR-PNW-163; USDA Forest Service, Pacific Northwest Research Station: Portland, OR, USA, 1983; pp. 239-242.

44. Price, S.P.; Bradford, M.A.; Ashton, M.S. Characterizing organic carbon stocks and flows in forest soils. In Managing Forest Carbon in a Changing Environment; Ashton, M.S., Tyrrell, M.L., Spalding, D., Gentry, B., Eds.; Springer Science and Business Media: New York, NY, USA, 2012; pp. 7-30.

45. Zinn, Y.L.; Lal, R.; Bigham, J.M.; Resck, D.V.S. Edaphic controls on soil organic carbon retention in the Brazilian Cerrado: Texture and mineralogy. Soil Sci. Soc. Am. J. 2007, 71, 1204-1214. [CrossRef]

46. Kaiser, K.; Guggenberger, G. The role of DOM sorption to mineral surfaces in the preservation of organic matter in soils. Org. Geochem. 2000, 31, 711-725. [CrossRef]

47. Kayahara, G.J.; Klinka, K.; Lavkulich, L.M. Effects of decaying wood on eluviation, podzolization, acidification and nutrition in soils with different moisture regimes. Environ. Monit. Assess. 1991, 39, 485-492. [CrossRef] [PubMed]

48. Kalbitz, K.; Schwesig, D.; Rethemeyer, J.; Matzner, E. Stabilization of dissolved organic matter by sorption to the mineral soil. Soil Bio. Biochem. 2005, 37, 1319-1331. [CrossRef]

49. Gutiérrez del Arroyo, O.; Silver, W.L. How deep does disturbance go? The legacy of hurricanes on tropical forest soil biogeochemistry. In Proceedings of the American Geophysical Union Meeting, San Francisco, CA, USA, 12-16 December 2016; Available online: https://agu.confex.com/agu/fm16/meetingapp.cgi/Paper/ 168890 (accessed on 21 October 2016).

50. Turner, B.L.; Yavitt, J.B.; Harms, K.E.; Garcia, M.N.; Wright, S.J. Seasonal changes in soil organic matter after a decade of nutrient addition in a lowland tropical forest. Biogeochemistry 2015, 123, 221-235. [CrossRef]

51. Cobb, T.P.; Hannam, K.D.; Kishchuk, B.E.; Langor, D.W.; Quideau, S.A.; Spence, J.R. Wood-feeding beetles and soil nutrient cycling in burned forests: Implications of post-fire salvage logging. Agric. For. Entomol. 2010, 12, 9-17. [CrossRef]

52. Boddy, L.; Watkinson, S.C. Wood decomposition, higher fungi, and their role in nutrient redistribution. Can. J. Bot. 1995, 73, S1377-S1383. [CrossRef]

53. Boddy, L. Saprotrophic cord-forming fungi: Meeting the challenge of heterogeneous environments. Mycologia 1999, 91, 13-32. [CrossRef]

54. Ulyshen, M.D. Insect-mediated nitrogen dynamics in decomposing wood. Ecol. Entomol. 2015, 40 (Suppl. 1), 97-112. [CrossRef]

55. Ausmus, B.S. Regulation of wood decomposition rates by arthropod and annelid populations. Ecol. Bull. 1977, 25, 180-192. 
56. Lang, G.E.; Knight, D.H. Decay rates for boles of tropical trees in Panama. Biotropica 1979, 11, $316-317$. [CrossRef]

57. Torres, J.A.; González, G. Wood Decomposition of Cyrilla racemiflora (Cyrillaceae) in Puerto Rican Dry and Wet Forests: A 13-year Case Study. Biotropica 2005, 37, 452-456. [CrossRef]

58. Shiels, A.; González, G.; Lodge, D.J.; Willig, M.R.; Zimmerman, J.K. Cascading effects of canopy opening and debris deposition from a large-scale hurricane experiment in a tropical rainforest. Bioscience 2015, 65, 871-881. [CrossRef]

59. Bouget, C.; Duelli, P. The effects of windthrow on forest insect communities: A literature review. Biol. Conserv. 2004, 118, 281-299. [CrossRef]

60. Swift, M.J.; Boddy, L. Animal-microbial interactions in wood decomposition. In Invertebrate-Microbial Interactions; Anderson, J.M., Rayner, A.D.M., Walton, D.W.H., Eds.; Cambridge University Press: Cambridge, UK, 1984; pp. 89-131.

61. Winsor, G.W.; Pollard, A.G. Carbon-nitrogen relationships in soil. IV. Mineralization of carbon and nitrogen. J. Sci. Food Agric. 1956, 7, 618-624. [CrossRef]

62. Cleveland, C.C.; Liptzin, D. C:N:P stoichiometry in soil: Is there a 'Redfield' ratio for the microbial biomass? Biogeochemistry 2007, 85, 235-252. [CrossRef]

63. Zalamea, M.; González, G. Leaf fall phenology in a subtropical wet forest in Puerto Rico: From species to community patterns. Biotropica 2008, 40, 295-304. [CrossRef]

64. González, G.; Lodge, D.J.; Richardson, B.A.; Richardson, M.J. A canopy trimming experiment in Puerto Rico: The response of litter decomposition and nutrient release to canopy opening and debris deposition in a subtropical wet forest. For. Ecol. Manag. 2014, 332, 32-46. [CrossRef]

65. Silver, W.L.; Hall, S.J.; González, G. Differential effects of canopy trimming and litter deposition on litterfall and nutrient dynamics in a wet subtropical forest. For. Ecol. Manag. 2014, 332, 47-55. [CrossRef]

66. Lodge, D.J.; Scatena, F.N.; Asbury, C.E.; Sánchez, M.J. Fine litterfall and related nutrient inputs resulting from Hurricane Hugo in subtropical wet and lower montane tropical forest of Puerto Rico. Biotropica 1991, 23, 336-342. [CrossRef]

67. Zou, X.; Zucca, C.P.; Waide, R.B.; McDowell, W.H. Long-term influence of deforestation on tree species composition and litter dynamics of a tropical rain forest in Puerto Rico. For. Ecol. Manag. 1995, 78, 147-157. [CrossRef]

68. Lodge, D.J. Nutrient cycling by fungi in wet tropical forests. In Aspects of Tropical Mycology; BMS Symposium Series 19; Isaac, S., Frankland, J.C., Watling, R., Whalley, A.J.S., Eds.; Cambridge University Press: Cambridge, UK, 1993; pp. 37-57.

69. Bouskill, N.J.; Lim, H.C.; Borglin, S.; Salve, R.; Wood, T.E.; Silver, W.L. Pre-exposure to drought increases the resistance of tropical forest soil bacterial communities to extended drought. ISME J. 2013, 7, 384-394. [CrossRef] [PubMed]

70. Bouskill, N.J.; Wood, T.E.; Baran, R.; Ye, Z.; Bowen, B.P.; Lim, H.C.; Zhou, J.; Van Norstrand, J.D.; Nico, P.; Northern, T.R.; et al. Belowground response to drought in a tropical forest soil. I. Changes in microbial functional potential and metabolism. Front. Microbiol. 2016, 7, 525. [CrossRef] [PubMed]

71. Paul, E.A.; Clark, E.E. Soil Microbiology and Biochemistry; Academic Press: San Diego, CA, USA, 1996.

72. Khan, D.; Sahito, Z.A.; Dawar, S.; Zaki, M.J. Frass of saproxylic-cerambycid larvae from dead twigs of Acacia stenophylla A. Cunn. EX. Benth. and its effects on germination and seedling growth of Lactuca sativa L. var. grand rapids. Int. J. Biol. Biotechnol. 2016, 13, 461-470.

(C) 2016 by the authors; licensee MDPI, Basel, Switzerland. This article is an open access article distributed under the terms and conditions of the Creative Commons Attribution (CC-BY) license (http://creativecommons.org/licenses/by/4.0/). 